\title{
Equilibrium and Kinetic Parameters Determination of Cr(VI) Adsorption by Hogla Leaves (Typha elephantina Roxb.)
}

\section{Moniruzzaman ${ }^{1 *}$, MA Rahman ${ }^{2}$, S Aktar ${ }^{1}$ and M Khan ${ }^{1}$}

${ }^{1}$ Designated Reference Institute for Chemical Measurements (DRiCM), Bangladesh Council of Scientific \& Industrial Research (BCSIR), Dr. Kudrat- i- Khuda Road, Dhanmondi, Dhaka, Bangladesh

${ }^{2}$ Institute of Nuclear Medical Physics (INMP), Bangladesh Atomic Energy Commission (BAEC), Savar, Dhaka, Bangladesh

\begin{abstract}
Equilibrium and kinetic parameters of $\mathrm{Cr}(\mathrm{VI})$ adsorption on Hogla leaves (Typha Elephantina Roxb.) were determined in a batch process. Batch adsorption experiments were carried out as a function of $\mathrm{pH}$, adsorbent dosage and initial metal ion concentration. Maximum metal adsorption was found to occur at $\mathrm{pH} 2.0$. The adsorption capacity of studied adsorbent was found to be $30.616 \mathrm{mg} / \mathrm{g}$ for initial $\mathrm{Cr}(\mathrm{VI})$ concentration of $400 \mathrm{ppm}$ and optimum adsorbent dose of $10 \mathrm{~g} / \mathrm{L}$ at $25^{\circ} \mathrm{C}$. Compared to the Freundlich isotherm model, the Langmuir and Temkin model best fit the experimental data $\left(R^{2}>0.995\right)$. Batch adsorption models, based on the assumption of the pseudo firstorder and pseudo second order mechanism were applied to examine the kinetics of the adsorption. The results of this study demonstrated that the pseudo-second order model was more suitable than pseudo-first order model for adsorption of $\mathrm{Cr}(\mathrm{VI})$ by Hogla leaves. At $25^{\circ} \mathrm{C}$, with a contact time of 360 minutes and agitation rate of $180 \mathrm{rpm}$, the potential of $\mathrm{Cr}(\mathrm{VI})$ removal by Hogla leaves from industrial effluent was also investigated at optimized condition of $\mathrm{pH} 2.0$, initial metal ion concentration of $400 \mathrm{ppm}$ and adsorbent dose of $10 \mathrm{~g} / \mathrm{L}$ and removal efficiency was found to be $44.8 \%$.
\end{abstract}

Keywords: Hogla leaves; Adsorption; Adsorbent; $\mathrm{Cr}(\mathrm{VI})$

\section{Introduction}

Heavy metals such as mercury, lead, cadmium, copper, chromium and nickel are extremely toxic even in minute quantities [1]. Chromium is more abundant in earth's crust and is widely used in electroplating, leather tanning, metal finishing and chromate preparation. It exists in two stable oxidation states $\mathrm{Cr}(\mathrm{III})$ and $\mathrm{Cr}(\mathrm{VI})$. $\mathrm{Cr}(\mathrm{VI})$ is of particular concern as because of its high toxicity, it may cause many adverse effects on human health such as epigastric pain, hemorrhage, severe diarrhea, vomiting, nausea, dermatitis by skin contact, ulcer, lung cancer and tissue necrosis. The allowable limit of $\mathrm{Cr}(\mathrm{VI})$ for the discharge of inland surface water is $0.1 \mathrm{ppm}$ [2]. Therefore, it has become an essential to remove $\mathrm{Cr}(\mathrm{VI})$ from industrial waste water before discharging it into water body or on to land.

Conventional technology for the removal of metal ions from aqueous solution includes chemical precipitation, ion exchange, chemical oxidation/reduction, reverse osmosis, electrodialysis, ultrafiltration, etc. which have their own inherent limitations such incomplete metal removal, requirements for expensive equipment and monitoring system, high reagent or energy requirements or generation of toxic sludge or other waste products that require disposal [3]. Adsorption is a physiochemical wastewater treatment process, which is gaining prominence as a means of producing high-quality effluents, which are low in metal ion concentrations. Natural materials which are available in large quantities or certain waste products from industries or agriculture have drawn attentions to researchers to be used as inexpensive adsorbents. Some of these are tea factory waste [4], eucalyptus bark [5], Hevea brasilinesis sawdust [6], beech sawdust [7], the agricultural byproduct of Lentinus edodes [8], non-living microbial biomass [9], fresh water algae [10], clay mineral [11], phosphate rock [12], etc. Among these adsorbents the ability of biological materials to adsorb metal ions has drawn considerable attention for the development of an efficient, clean and cheap technology for wastewater treatment [4].

Hogla, local name for a bush-like small plant, Typha elephantina Roxb. of family Typhaceae. The plants look like grasses and may attain heights from two to five meters. The leaf blades are flattened and composed of aerenchymatous spongy tissue [13]. In Bangladesh Hogla is frequently seen in the North-Eastern part of the country especially along the banks of rivers and canals. Hogla grass is extensively used to make mats, baskets, ropes and different kinds of handicrafts. Beside these house hold applications, anther application of Hogla leaves as low cost adsorbents can be explored. In many adsorption studies, activated carbon derived from many agricultural sources are being used as an adsorbent. Low cost and availability of Hogla leaves might be a suitable alternative of activated carbons. The objective of this study is to determine the equilibrium and kinetic parameters of $\mathrm{Cr}(\mathrm{VI})$ adsorption onto dried Hogla leaves by fitting the experimental data into various mathematical models such as Langmuir's, Freundlich's and Temkin's models for sorption isotherms and pseudo first- and second- order rate equations for description of kinetics. And also to investigate the potential of Hogla leaves for removal of $\mathrm{Cr}(\mathrm{VI})$ from industrial effluents.

\section{Materials and Methods}

\section{Adsorbents}

Hogla leaves were collected from a village of Jessore, Bangladesh. After collection of dried leaves, it was then categorized into four subgroups NW (Normal Washed), NWP (Normal Washed Powder), AW (Acid Washed) \& AWP (Acid Washed Powder). NW category

*Corresponding author: Moniruzzaman M, Designated Reference Institute for Chemical Measurements (DRiCM), Bangladesh Council of Scientific \& Industrial Research (BCSIR), Dr. Kudrat- i- Khuda Road, Dhanmondi, Dhaka- 1205, Bangladesh. Tel: +8801718562292; E-mail: mzamancep@yahoo.com

Received September 12, 2017; Accepted September 25, 2017; Published October 02, 2017

Citation: Moniruzzaman M, Rahman MA, Aktar S, Khan M (2017) Equilibrium and Kinetic Parameters Determination of $\mathrm{Cr}(\mathrm{VI})$ Adsorption by Hogla Leaves (Typha elephantina Roxb.). Int J Waste Resour 7: 301. doi: 10.4172/2252-5211.1000301

Copyright: (c) 2017 Moniruzzaman M, et al. This is an open-access article distributed under the terms of the Creative Commons Attribution License, which permits unrestricted use, distribution, and reproduction in any medium, provided the original author and source are credited. 
adsorbent was prepared by washing followed by drying. NWP was prepared by washing followed by drying and then grinding. AW was prepared by washing with $5 \%$ hydrochloric acid solution. After that it was dried. AWP was prepared by washing with $5 \%$ hydrochloric acid solution followed by drying and grinding. All washing was done by deionized water. Drying was carried out in a drying oven at $100-105^{\circ} \mathrm{C}$.

\section{Preparation of $\mathrm{Cr}(\mathrm{VI})$ solution}

$500 \mathrm{ppm}$ of $\mathrm{Cr}(\mathrm{VI})$ solution was prepared by dissolving $1.414 \mathrm{~g}$ of potassium dichromate $\left(\mathrm{K}_{2} \mathrm{Cr}_{2} \mathrm{O}_{7}\right)$ in $1 \mathrm{~L}$ deionized water. Experimental solutions at the desired concentration were obtained by appropriate dilutions. Fresh dilutions were used for each experiment. The $\mathrm{pH}$ adjustments were carried out either by sulfuric acid and sodium hydroxide.

\section{Batch adsorption experiments}

Batch process was employed for adsorption studies. Pre weighted sample of the adsorbent and a measured volume of $\mathrm{Cr}(\mathrm{VI})$ solution were taken in $250 \mathrm{~mL}$ Erlenmeyer flask. The mixture was agitated at 180 rpm for 360 min to ensure equilibrium and then it was filtered through filter paper (Whatman 44). Cr(VI) concentration in the adsorbate was determined using an indirect UV-vis spectrophotometric method based on the reaction of $\mathrm{Cr}(\mathrm{VI})$ and diphenyl carbazide, which forms a red-violet colored complex. The absorbance of the colored complex was measured in a double beam spectrophotometer at $540 \mathrm{~nm}$ wavelength spectrometrically [14] Shimadzu UV-1800 UV - spectrophotometer. All the experiments were carried out at least three times.

\section{Results and Discussion}

\section{Selection of adsorbents}

The four category adsorbent prepared from hogla leaves were taken in equal amount in different $250 \mathrm{~mL}$ Erlenmeyer flask. The initial $\mathrm{Cr}(\mathrm{VI})$ ion concentration and $\mathrm{pH}$ of the solution were same at each flask and were shaked with adsorbent at the same rpm for the same period of time. It was found that AWP Hogla exhibits the highest removal of $\mathrm{Cr}(\mathrm{VI})$ then other three (Figure 1). Acid wash has sufficiently freed the active sites of the adsorbents and grinding increased the surface area promoting a great number of active sites to adsorb $\mathrm{Cr}(\mathrm{VI})$ from solution. Therefore, AWP Hogla adsorbent was chosen and all the experiments were conducted using this adsorbent.

\section{Fourier transform infrared spectroscopy (FTIR) analysis}

The functional groups before and after adsorption of $\mathrm{Cr}(\mathrm{VI})$ onto AWP Hogla and the corresponding infrared adsorption bands are shown in Table 1 . The infrared spectra were obtained using Shimadzu IR Prestige-21 FTIR spectrophotometer. The FTIR spectra before and after adsorption of AWP Hogla are shown in Figures $2 a$ and $2 b$ respectively.

Metal ions are generally caught by carboxylic, phenolic, hydroxylic, carbonyl groups [15]. As shown in Figures $2 \mathrm{a}$ and $2 \mathrm{~b}$ and Table 1, the spectra displayed a number of adsorption peaks which indicates the active functional groups present in AWP Hogla. These peak shifts indicated that the bonded $\mathrm{OH}$ stretching, alkane $\mathrm{C}-\mathrm{H}$ stretching, $\mathrm{O}=\mathrm{C}=\mathrm{O}$ stretching, and $\mathrm{C}=\mathrm{C}$ stretching were mainly responsible for the adsorption of $\mathrm{Cr}(\mathrm{VI})$ onto AWP Hogla [16].

\section{Effect of pH on $\mathrm{Cr}(\mathrm{VI})$ adsorption}

The effect of $\mathrm{pH}$ on $\mathrm{Cr}(\mathrm{VI})$ removal by AWP (acid washed powder) Hogla was investigated at constant adsorbent dose and contact time by

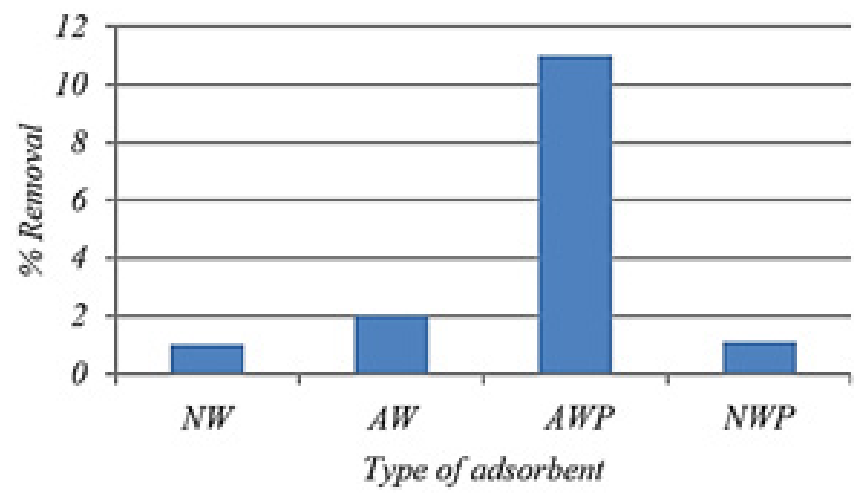

Figure 1: Prepared adsorbent type versus \% removal of $\mathrm{Cr}(\mathrm{VI})$.
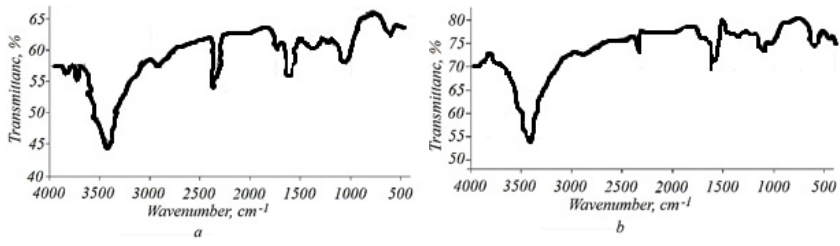

Figure 2: The FTIR spectra of AWP Hogla: a - before adsorption, b - after adsorption. Conditions: $\mathrm{pH} 2.0$, initial $\mathrm{Cr}(\mathrm{VI})$ concentration $-200 \mathrm{ppm}$, contact time $-360 \mathrm{~min}$, agitation rate $-180 \mathrm{rpm}$, temperature $-25^{\circ} \mathrm{C}$.

\begin{tabular}{|c|c|c|c|c|}
\hline \multirow{2}{*}{$\begin{array}{c}\text { IR } \\
\text { peak }\end{array}$} & \multicolumn{3}{|c|}{ Adsorption bands, $\mathbf{c m}^{-1}$} & \multirow[b]{2}{*}{ Assignment } \\
\hline & $\begin{array}{c}\text { Before } \\
\text { adsorption }\end{array}$ & $\begin{array}{c}\text { After } \\
\text { adsorption }\end{array}$ & Difference & \\
\hline 1 & 3527 & 3522 & -5 & Bonded $-\mathrm{OH}$ stretching \\
\hline 2 & 3473 & 3466 & -7 & Bonded $-\mathrm{OH}$ stretching \\
\hline 3 & 3412 & 3412 & 0 & Bonded $-\mathrm{OH}$ stretching \\
\hline 4 & 2906 & 2922 & +16 & Alkane $\mathrm{C}-\mathrm{H}$ stretching \\
\hline 5 & 2370 & 2358 & -12 & $\mathrm{O}=\mathrm{C}=\mathrm{O}$ stretching \\
\hline 6 & 1610 & 1635 & +28 & $\mathrm{C}=\mathrm{C}$ stretching \\
\hline 7 & 1109 & 1109 & 0 & $\begin{array}{c}\text { Secondary alcohol C-O } \\
\text { stretching }\end{array}$ \\
\hline
\end{tabular}

Table 1: FTIR spectral characteristics of AWP Hogla before and after adsorption. varying $\mathrm{pH}$ from 2.0-12.0. Progressive increase in $\mathrm{Cr}(\mathrm{VI})$ adsorption was observed with decrease in $\mathrm{pH}$ from 12 to 2 and maximum adsorption was observed at $\mathrm{pH} 2$ (Figure 3). AWP showed the maximum removal of $73.6 \%$ at $\mathrm{pH} 2$.

The effect of $\mathrm{pH}$ on adsorption of $\mathrm{Cr}(\mathrm{VI})$ onto the adsorbent can be interpreted on the basis of the structure of the sorbent and the speciation of chromium. Chromium solution contains a larger number of $\mathrm{Cr}_{2} \mathrm{O}_{7}^{2-}$ ions and a smaller number of $\mathrm{HCrO}_{4}^{-}$ions in the regions of lower $\mathrm{pH}$ and only $\mathrm{CrO}_{4}^{2-}$ ions above $\mathrm{pH}$ 8.0. In the $\mathrm{pH}$ range 3 to 6 , the equilibrium shifts to dichromate according to the overall equilibrium [16]:

$$
2 \mathrm{CrO}_{4}^{2-}+2 \mathrm{H}^{+}=\mathrm{Cr}_{2} \mathrm{O}_{7}^{2-}+\mathrm{H}_{2} \mathrm{O} \text {. }
$$

A major fraction of negative sites are occupied by $\mathrm{H}^{+}$ions via electrostatic attraction in the regions of lower $\mathrm{pH}$ and these positively charged sites of the adsorbent are occupied by $\mathrm{Cr}_{2} \mathrm{O}_{7}^{2-}$ ions [17]. Hence, the maximum chromium removal was observed at lower $\mathrm{pH}$ i.e., 2. Higher removal of chromium at low $\mathrm{pH}$ may also be due to the reduction of chromium (VI) to chromium (III) $[18,19]$, which was then adsorbed by the adsorbent. 


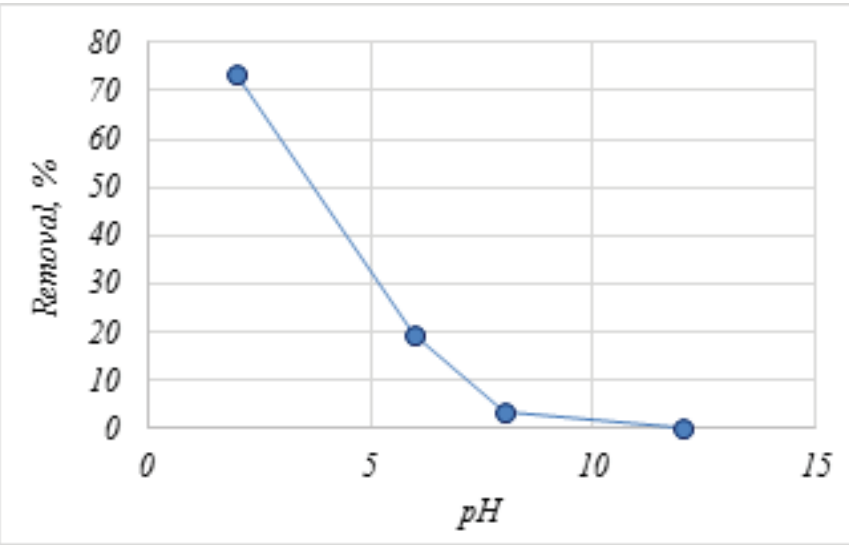

Figure 3: Effect of $\mathrm{pH}$ conditions: AWP adsorbent dose $-5 \mathrm{~g} / \mathrm{L}$, initial $\mathrm{Cr}(\mathrm{VI})$ concentration - $100 \mathrm{ppm}$, contact time $-360 \mathrm{~min}$, agitation rate $-180 \mathrm{rpm}$, temperature $-25^{\circ} \mathrm{C}$.

\section{Effect of adsorbent dose}

To investigate the effect of adsorbent dosage, the adsorption of $\mathrm{Cr}(\mathrm{VI})$ onto AWP Hogla was measured at five different adsorbent dosage $(2.5,5,7.5,10$ and $15 \mathrm{~g} / \mathrm{L})$ for initial $\mathrm{Cr}(\mathrm{VI})$ concentration of $100 \mathrm{ppm}$ and the percent removal were presented in (Figure 4). When the adsorbent dosage was increased from 2.5 to $15 \mathrm{~g} / \mathrm{L}$, the removal increased from $32.68 \%$ to $78.5 \%$. It is obvious that the percent removal of heavy metals increases rapidly with increase in the adsorbent dose due to the greater availability of the exchangeable sites or surface area. However, very slow increase in removal beyond an optimum dose may be attributed to the attainment of equilibrium between adsorbate and adsorbent at the existing operating conditions [20]. Higher adsorbent dose cause screening effect of a dense outer layer of cells, blocking the binding sites from metal ions, resulting in lower metal removal per unit adsorbent [21]. The optimum dose for the removal of $\mathrm{Cr}(\mathrm{VI})$ was found to be $10 \mathrm{~g} / \mathrm{L}$ with removal efficiency of $78.71 \%$.

\section{Effect of initial $\mathrm{Cr}(\mathrm{VI})$ concentration}

The driving force to overcome the mass transfer restriction of molecules between aqueous and solid surface can be predicted by varying the initial metal ion concentration $[22,23]$. Effect of initial $\mathrm{Cr}(\mathrm{VI})$ ion concentration on its removal was carried out at optimized adsorbent dose, contact time and $\mathrm{pH}$ by varying the metal ion concentration from 150-400 ppm (Figure 5).

Figure 5 shows that the adsorption of $\mathrm{Cr}(\mathrm{VI})$ increases with increase in metal ion concentration from $150-300 \mathrm{ppm}$. This may be due to the interaction between the adsorbates and adsorbent, creating some new adsorption sites or the increased rate of intraparticle diffusion of $\mathrm{Cr}(\mathrm{VI})$ ions into the pores of the adsorbent [6]. The decrease in adsorption of $\mathrm{Cr}(\mathrm{VI})$ for initial metal concentration of $400 \mathrm{ppm}$ is due to increase in number of metal ions competing for available binding sites and due to lack of free binding sites [24] or due to the development of a barrier by the adsorbed $\mathrm{Cr}(\mathrm{VI})$ molecule surrounding the molecular surface of the adsorbents.

\section{Adsorption isotherm}

An adsorption isotherm is characterized by certain constant values that express the surface properties and affinity of the adsorbent and can be used to compare the adsorptive capacities of the adsorbent for different pollutants [25]. The experimental data showed in Table $2 \mathrm{a}$

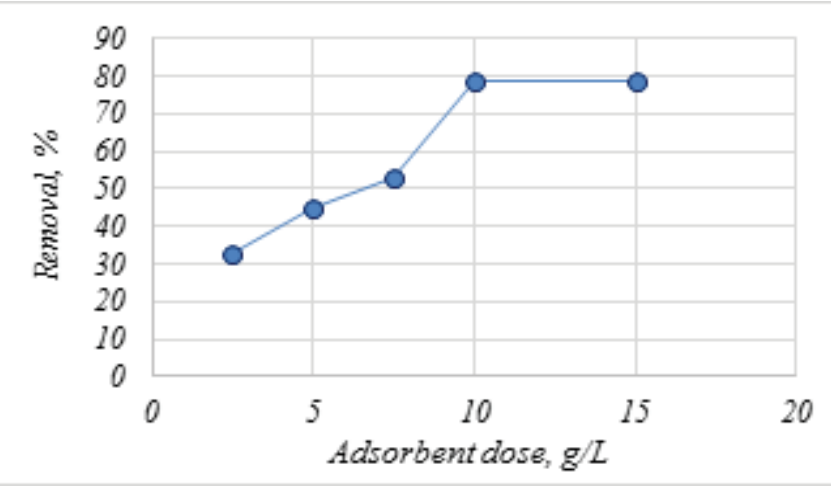

Figure 4: Effect of AWP adsorbent dose. Conditions: $\mathrm{pH} 2.0$, initial $\mathrm{Cr}(\mathrm{VI})$ concentration - $100 \mathrm{ppm}$, contact time $-360 \mathrm{~min}$, agitation rate $-180 \mathrm{rpm}$, temperature $-25^{\circ} \mathrm{C}$.

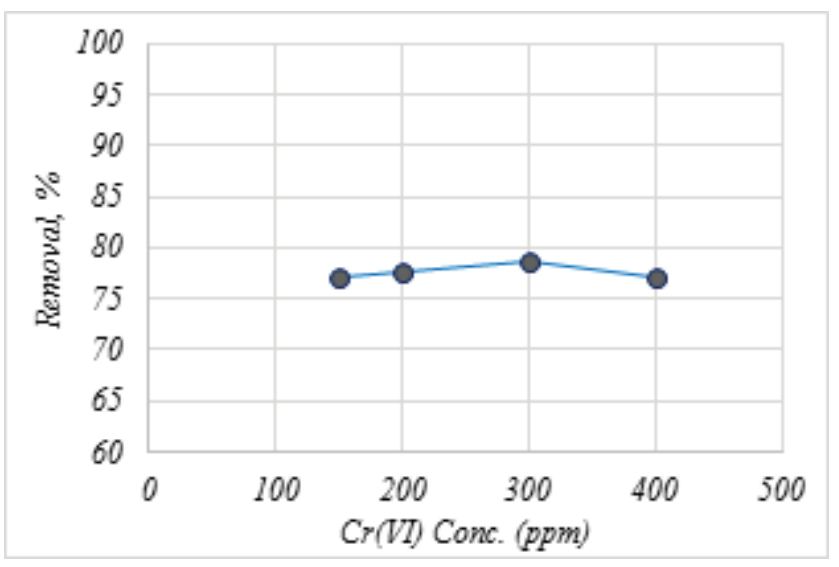

Figure 5: Effect of initial $\mathrm{Cr}(\mathrm{VI})$ concentration. Conditions: $\mathrm{pH}$ 2.0, AWP adsorbent dose $-10 \mathrm{~g} / \mathrm{L}$, agitation rate $-180 \mathrm{rpm}$, contact time $-360 \mathrm{~min}$, temperature $-25^{\circ} \mathrm{C}$.

were applied to the Langmuir, Freundlich, D-R, Temkin, Frumkin, and Harkins-Jura isotherm, in order to determine the mechanism of $\mathrm{Cr}(\mathrm{VI})$ adsorption on AWP Hogla.

The constant parameters of the isotherm equations for this adsorption process were calculated by regression using a linear form of the isotherm equations. The constant parameters and correlation coefficient $\left(\mathrm{R}^{2}\right)$ are tabulated in Table $2 \mathrm{~b}$.

\section{Langmuir isotherm model}

$$
\frac{1}{\mathrm{qe}}=\left[\frac{1}{\mathrm{QoK}}\right] \frac{1}{\mathrm{Ce}}+\frac{1}{\mathrm{Qo}}
$$

Where, $\mathrm{C}_{\mathrm{e}}$ - the equilibrium concentration, ppm, $\mathrm{q}_{\mathrm{e}}-$ the amount absorbed at equilibrium, mg/g, $\mathrm{Q}_{0}$ and $\mathrm{K}$ - the Langmuir constants related to adsorption capacity and energy of adsorption.

The essential features of a Langmuir isotherm can be expressed in terms of a dimensionless constant separation factor or equilibrium parameter, $\mathrm{R}_{\mathrm{L}}$ that is used to predict if an adsorption system is "favorable" or "unfavorable". The separation factor, $\mathrm{R}_{\mathrm{L}}$ is defined by Equation (2):

$$
\mathrm{R}_{\mathrm{L}}=\frac{1}{1+\mathrm{KC}_{\mathrm{o}}}
$$

Where, $\mathrm{C}_{\mathrm{o}}$ - the initial $\mathrm{Cr}(\mathrm{VI})$ concentration, ppm, $\mathrm{K}$ - the 


\begin{tabular}{|c|c|c|}
\hline $\begin{array}{l}C_{o} \text {, Initial } \mathrm{Cr}(\mathrm{VI}) \\
\text { Conc. (ppm) }\end{array}$ & $\begin{array}{l}C_{\mathrm{e}}, \text { Equilibrium } \\
\text { Conc. (ppm) }\end{array}$ & $\begin{array}{c}q_{\mathrm{e}} \text {, amount absorbed at equilibrium } \\
(\mathrm{mg} / \mathrm{g})\end{array}$ \\
\hline 150 & 34.272 & 11.573 \\
\hline 200 & 44.676 & 15.532 \\
\hline 300 & 64.26 & 23.574 \\
\hline 400 & 91.29 & 30.871 \\
\hline
\end{tabular}

Table 2a: Experimental data for adsorption isotherm.

\begin{tabular}{|c|c|}
\hline Langmuir isotherm & \\
\hline$Q_{o}, \mathrm{mg} / \mathrm{g}$ & 416.667 \\
\hline$K, \mathrm{~L} / \mathrm{g}$ & 0.0008 \\
\hline$R^{2}$ & 0.995 \\
\hline Freundlich isotherm & \\
\hline$K_{f} \mathrm{~L} / \mathrm{g}$ & 0.327 \\
\hline$n$ & 1.015 \\
\hline$R^{2}$ & 0.992 \\
\hline Temkin isotherm & \\
\hline$A, \mathrm{~L} / \mathrm{g}$ & 0.0505 \\
\hline$B$ & 20.055 \\
\hline$R^{2}$ & 0.995 \\
\hline
\end{tabular}

Table 2b: Isotherm constants for adsorption of $\mathrm{Cr}(\mathrm{VI})$ on $A W P$ Hogla.

Langmuir adsorption equilibrium constant, L/g.

The isotherm is unfavorable when $\mathrm{R}_{\mathrm{L}}>1$, the isotherm is linear when $\mathrm{R}_{\mathrm{L}}=1$, the isotherm is favorable when $0<\mathrm{R}_{\mathrm{L}}<1$ and the isotherm is irreversible when $R_{L}=0 . R_{L}$ values are $0.893,0.862,0.806$ and 0.757 while initial $\mathrm{Cr}(\mathrm{VI})$ concentrations are $150,200,300$ and $400 \mathrm{ppm}$ respectively. The values of $\mathrm{R}_{\mathrm{L}}$ for adsorption of $\mathrm{Cr}(\mathrm{VI})$ on AWP Hogla studied at different concentrations were between 0 and 1 indicating favorable adsorption of chromium on AWP Hogla.

\section{Freundlich isotherm model}

$$
\mathrm{q}_{\mathrm{e}}=\mathrm{K}_{\mathrm{f}} \mathrm{C}_{\mathrm{e}}^{\mathrm{n}}
$$

Where, $\mathrm{q}_{e}$ - the amount absorbed at equilibrium, mg/g, $\mathrm{C}_{e}-$ the equilibrium concentration, $\mathrm{ppm}, \mathrm{K}_{\mathrm{p}} \mathrm{n}-$ the Freundlich model constants.

\section{Temkin isotherm}

The derivation of the Temkin isotherm assumes that the fall in the heat of sorption is linear rather than logarithmic, as implied in the Freundlich equation. The Temkin isotherm has generally been applied in the following form. Temkin isotherm model is shown in Equation (4):

$$
\begin{aligned}
& q_{e}=\frac{R T}{b} \ln \left(A C_{e}\right) \\
& q_{e}=B \ln A+B \ln C_{e}
\end{aligned}
$$

Where, $B=(R T / b), q_{e}-$ the amounts absorbed at the equilibrium concentration, $\mathrm{mg} / \mathrm{g}, \mathrm{C}_{\mathrm{e}}-$ the amounts absorbed at the equilibrium concentration, ppm, $\mathrm{T}$ - the absolute temperature, $\mathrm{K}, \mathrm{R}$ - the universal gas constant, $8.314 \mathrm{~J} /(\mathrm{mol} \cdot \mathrm{K})$. The constant $\mathrm{b}$ is related to the heat of adsorption [26,27].

From Table $2 \mathrm{~b}$ (based on correlation coefficient) and Figures 6-8, it was seen that the adsorption of $\mathrm{Cr}(\mathrm{VI})$ onto AWP Hogla best fits into the Langmuir and Temkin isotherm model $\left(\mathrm{R}^{2}>0.995\right)$. The experimental data also fits quite well into the Freundlich isotherm model $\left(\mathrm{R}^{2}>0.992\right)$.

As seen from Figure 6, the Langmuir isotherm for adsorption of $\mathrm{Cr}(\mathrm{VI})$ onto AWP Hogla was found to be linear and the correlation

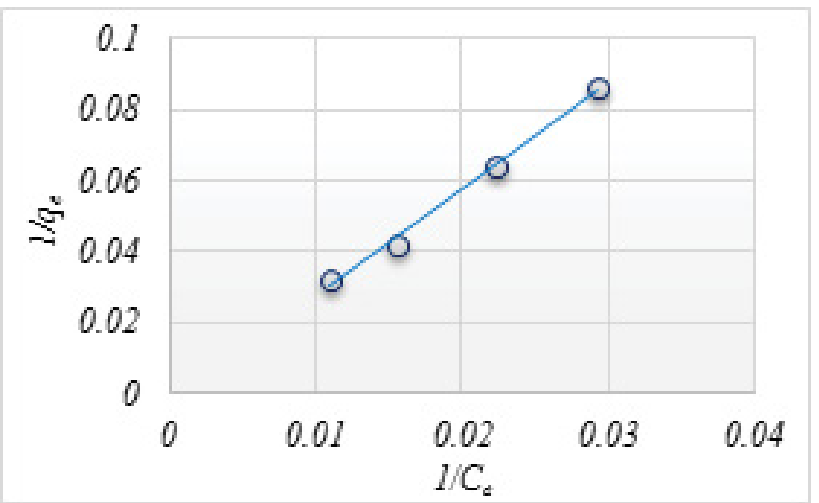

Figure 6: Langmuir isotherm.

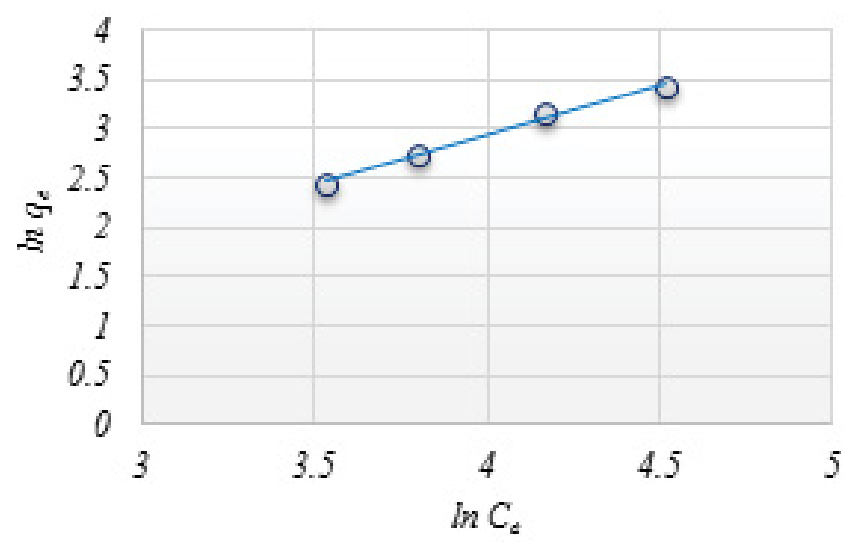

Figure 7: Freundlich isotherm.

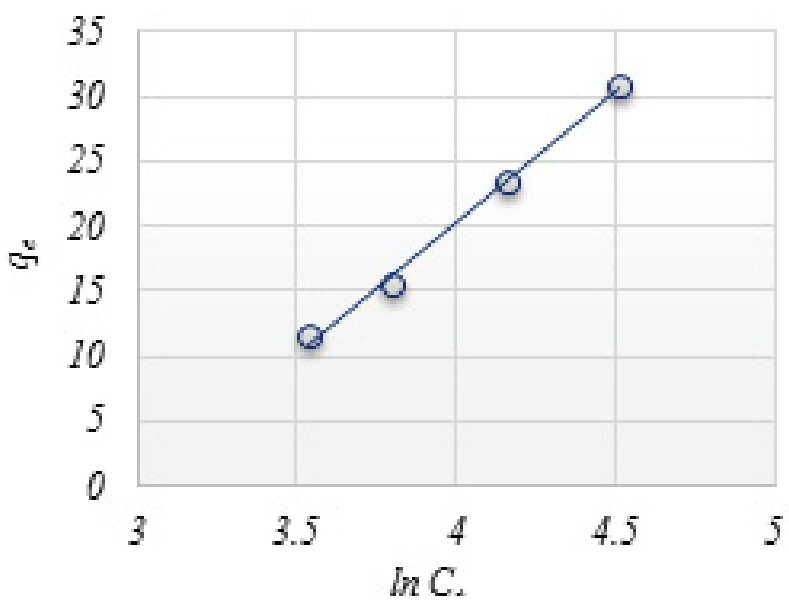

Figure 8: Temkin isotherm.

coefficient was extremely high as tabulated in Table $2 \mathrm{~b}$. It was seen from Figure 8 that the Temkin isotherm for $\mathrm{Cr}(\mathrm{VI})$ adsorption by AWP Hogla was also found to be linear and the correlation coefficient was as high as that of Langmuir isotherm, as seen in Table 2b. Since the Temkin isotherm constant (B) is related to the heat of adsorption, the adsorption of $\mathrm{Cr}(\mathrm{VI})$ onto AWP Hogla could think of as an endothermic adsorption [22]. From Figure 7, it was seen that the Freundlich isotherm also fits quite well for $\mathrm{Cr}(\mathrm{VI})$ adsorption by AWP Hogla. The correlation coefficient was also high as shown in Table $2 b$. The value of $n$ was found to be greater than 1 as shown in Table $2 b$, 
indicating favorable adsorption of $\mathrm{Cr}(\mathrm{VI})$ by AWP Hogla.

\section{Adsorption kinetics}

Using pseudo first-order and pseudo second-order kinetic models, the rate constants were calculated. The pseudo first-order expression is as follows:

$$
\log \left(q_{e}-q_{t}\right)=\log q_{e}-\frac{k_{1}}{2.303} t
$$

Where, $\mathrm{q}_{\mathrm{t}}$ - amount of adsorbed $\mathrm{Cr}(\mathrm{VI})$ on the adsorbent at time $\mathrm{t}$, $\mathrm{mg} / \mathrm{g}, \mathrm{k}_{1}$ - the rate constant of first-order adsorption, $\mathrm{min}^{-1}$.

A straight line of $\log \left(\mathrm{q}_{e}-\mathrm{q}_{\mathrm{t}}\right)$ versus $\mathrm{t}$ suggests the applicability of this kinetic model. $\mathrm{q}_{\mathrm{e}}$ and $\mathrm{k}_{1}$ can be determined from the intercept and slope of the plot respectively [28].

The pseudo second-order kinetic model can be expressed as:

$$
\frac{\mathrm{t}}{\mathrm{q}_{\mathrm{t}}}=\frac{1}{\mathrm{k}_{2} \mathrm{q}_{\mathrm{e}}^{2}}+\frac{1}{\mathrm{q}_{\mathrm{e}}} \mathrm{t}
$$

Where, $\mathrm{k}_{2}$ - the rate constant of second order adsorption, $\mathrm{g} /$ (mg.min). The pseudo second-order kinetics will be applicable if the plot $\mathrm{t} / \mathrm{q}_{\mathrm{t}}$ versus $\mathrm{t}$ gives a straight line. Then $\mathrm{q}_{\mathrm{e}}$ and $\mathrm{k}_{2}$ can be determined from the slope and intercept of the plot respectively.

Again:

$$
\mathrm{h}=\mathrm{k}_{2} \mathrm{q}_{\mathrm{e}}^{2}
$$

Where, $\mathrm{h}$ - the initial sorption rate, $\mathrm{mg} /(\mathrm{g} \cdot \mathrm{min})$ [29].

The pseudo first-order rate constants $\mathrm{k}_{1}$, pseudo second-order rate constants $\mathrm{k}_{2}$, the initial sorption rate $\mathrm{h}$, calculated equilibrium sorption capacity $\mathrm{q}_{\mathrm{e}}$ (the (theoretical), experimental equilibrium sorption capacity $\mathrm{q}_{e, \text { exp }}$ (experimental) and regression coefficients $\mathrm{R}_{2}$ at various initial $\mathrm{Cr}(\mathrm{VI})$ concentrations and at fixed temperature $\left(25^{\circ} \mathrm{C}\right)$ are given in Table 3. A comparison of $\mathrm{q}_{e, e x p}$ and $\mathrm{q}_{\mathrm{e} \text { theo }}$ results for various initial $\mathrm{Cr}(\mathrm{VI})$ concentration is shown in Figure 9.

From Table 3, it was seen that the regression coefficients for pseudo first- order kinetic model were much below than 0.96 which indicated a bad correlation. On the other hand, all the regression coefficients for the pseudo second- order kinetic model were found to be greater than 0.96 and thus indicated a good correlation. From Table 3 and Figure 9 , the $\mathrm{q}_{\mathrm{e}}$, the values estimated from the first order kinetic model gave different values compared to experimental values, except for the case of 200 and $300 \mathrm{ppm}$ and the correlation coefficients were also found to be fairly lower except for $400 \mathrm{ppm}$. However, for the case of the pseudosecond-order kinetic model the calculated $\mathrm{q}_{e, t h e o}$ values were quite close to $\mathrm{q}_{\text {eexp }}$ values at various initial $\mathrm{Cr}(\mathrm{VI})$ concentrations. Moreover, from Table 3 it was seen that the rate constants $k_{2}$, for the pseudo secondorder model decreases with increasing of initial $\mathrm{Cr}(\mathrm{VI})$ concentration, while the initial sorption rate $h$, increases with increasing initial $\mathrm{Cr}(\mathrm{VI})$ concentration. Comparing the values of regression coefficients $\mathrm{R}^{2}$, it was seen that the values for pseudo first- order model were pretty lower than those of pseudo second- order model for all the adsorption process and therefore it can be said that the pseudo-second order- the model was better obeyed than the pseudo first- order model. The kinetic study was done by other researchers for the adsorption of $\mathrm{Cr}(\mathrm{VI})$ also supports the previous statement $[6,30]$.

\section{Comparison of AWP Hogla with other adsorbents}

The metal uptake capacity of various adsorbents is different from one another. This is because of the properties of each adsorbent such

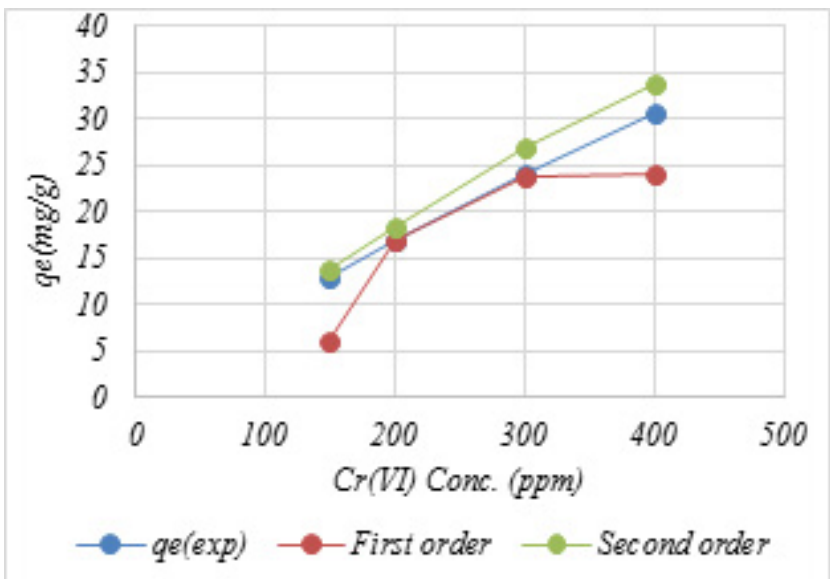

Figure 9: Comparison between the experimental $\left(\mathrm{q}_{\mathrm{e}, \mathrm{exp}}\right)$ and calculated $\left(\mathrm{q}_{\mathrm{e}, \text { theo }}\right)$ data for adsorption of $\mathrm{Cr}(\mathrm{VI})$ by AWP Hogla at $25^{\circ} \mathrm{C}$.

\begin{tabular}{|c|c|c|c|c|c|c|c|c|}
\hline $\begin{array}{c}\mathbf{C}_{\mathrm{o}} \\
\mathbf{p p m})\end{array}$ & $\begin{array}{c}\mathbf{q}_{\mathrm{e}, \mathrm{exp}} \\
(\mathbf{m g} / \mathbf{g})\end{array}$ & \multicolumn{3}{|c|}{$\begin{array}{c}\text { Pseudo first- order } \\
\text { kinetics }\end{array}$} & \multicolumn{3}{|c|}{ Pseudo second- order kinetics } \\
\hline & & $\mathrm{k}_{1}\left(\mathrm{~min}^{-1}\right)$ & $\mathrm{q}_{\mathrm{e}, \text { theo }}$ & $\mathrm{R}^{2}$ & $\begin{array}{c}\mathrm{k}_{2}\left(\mathrm{~g} \mathrm{mg}^{-1}\right. \\
\left.\mathrm{min}^{-1}\right)\end{array}$ & $\mathrm{q}_{\mathrm{e}, \text { theo }}$ & $\begin{array}{c}\mathrm{h}\left(\mathrm{mg} \mathrm{g}^{-1}\right. \\
\left.\mathrm{min}^{-1}\right)\end{array}$ & $\mathrm{R}^{2}$ \\
\hline 150 & 12.853 & 0.005 & 6.023 & 0.390 & 0.002 & 13.889 & 0.325 & 0.973 \\
\hline 200 & 16.879 & 0.013 & 16.866 & 0.767 & 0.001 & 18.315 & 0.378 & 0.969 \\
\hline 300 & 24.155 & 0.012 & 23.632 & 0.601 & 0.0007 & 26.810 & 0.475 & 0.973 \\
\hline 400 & 30.616 & 0.008 & 24.105 & 0.910 & 0.0005 & 33.784 & 0.553 & 0.967 \\
\hline
\end{tabular}

Table 3: A comparison of the pseudo first- order and pseudo second-order rate constants and theoretical and experimental $q_{e}$ values obtained at different initial $\mathrm{Cr}(\mathrm{VI})$ concentrations and at fixed temperature $25^{\circ} \mathrm{C}$.

as structure, functional groups, and surface areas. A comparison of adsorption capacity of $\mathrm{Cr}(\mathrm{VI})$ by AWP Hogla with other reported adsorbents is shown in Table 4 . It can be seen that for almost every case $\mathrm{pH} 2.0$ was the optimum condition for $\mathrm{Cr}(\mathrm{VI})$ adsorption whatever the adsorbent was. When compared with other adsorbents reported in literature elsewhere, the adsorption capacity of $\mathrm{Cr}(\mathrm{VI})$ by AWP Hogla was found to be higher with three exceptions.

\section{Industrial feasibility of adsorbent}

The industrial feasibility of AWP Hogla was studied for the removal of $\mathrm{Cr}(\mathrm{VI})$ from tannery effluent at optimized conditions obtained from experiments on a synthetic solution in batch mode. The removal efficiency of the adsorbent was reduced from $78.7 \%$ to $44.8 \%$. This reduction in percent removal may be due to the presence of co-metal ions and dyes present in industrial effluents [31-37].

\section{Conclusion}

The adsorption of $\mathrm{Cr}(\mathrm{VI})$ by AWP Hogla was dependent on $\mathrm{pH}$, adsorbent dose, and initial metal ion concentration. The adsorption capacity was highest at $\mathrm{pH}$ 2.0. The optimum dosage for $\mathrm{Cr}(\mathrm{VI})$ adsorption by AWP Hogla was found to be $10 \mathrm{~g} / \mathrm{L}$. Using Langmuir, Freundlich and Temkin isotherm, the adsorption of $\mathrm{Cr}(\mathrm{VI})$ onto AWP Hogla were described. Langmuir and Temkin's model showed better correlation coefficient than the other model in the studied concentration. Freundlich model also showed quite good correlation coefficient. The pseudo first- order and pseudo second- order kinetic model were used to analyze the data obtained for the adsorption of $\mathrm{Cr}(\mathrm{VI})$ onto AWP Hogla. The pseudo second- order equation was found to have the best correlation for the adsorption data. The AWP 
Citation: Moniruzzaman M, Rahman MA, Aktar S, Khan M (2017) Equilibrium and Kinetic Parameters Determination of Cr(VI) Adsorption by Hogla Leaves (Typha elephantina Roxb.). Int J Waste Resour 7: 301. doi: 10.4172/2252-5211.1000301

\begin{tabular}{|c|c|c|c|c|}
\hline Adsorbent & $\mathbf{q}_{\mathbf{e}}, \mathbf{m g} / \mathbf{g}$ & $\mathbf{p H}$ & $\begin{array}{c}\text { Max. conc., } \\
\mathbf{p p m}\end{array}$ & References \\
\hline Eucalyptus bark & 45.00 & 2.0 & 250 & {$[5]$} \\
\hline $\begin{array}{c}\text { Hevea brasiliensis sawdust activated } \\
\text { carbon }\end{array}$ & 42.64 & 2.0 & 200 & {$[6]$} \\
\hline $\begin{array}{c}\text { Beech sawdust } \\
\text { Waste acorn of Quercus } \\
\text { ithaburensis }\end{array}$ & 16.10 & 1.0 & 200 & {$[7]$} \\
\hline Maghemite nanoparticles & 31.48 & 2.0 & 400 & {$[16]$} \\
\hline Chlorella vulgaris & 19.20 & 2.5 & 200 & {$[31]$} \\
\hline Scenedesmus obliquus & 15.60 & 2.0 & 100 & {$[32]$} \\
\hline Synechocystis sp. & 19.20 & 2.0 & 100 & {$[32]$} \\
\hline Sugar cane bagasse & 13.40 & 2.0 & 500 & {$[33]$} \\
\hline Sugar beet pulp & 17.20 & 2.0 & 500 & {$[33]$} \\
\hline Coconut shell carbon & 10.88 & 4.0 & 25 & {$[34]$} \\
\hline HSAC & 17.70 & 2.0 & 30 & {$[35]$} \\
\hline Agave lechuguilla & 11.31 & 4.0 & 40 & {$[36]$} \\
\hline AWP Hogla & 30.616 & 2.0 & 400 & {$[38]$} \\
\hline
\end{tabular}

Table 4: Comparison of adsorption capacity of $\mathrm{Cr}(\mathrm{VI})$ with others.

Hogla was found quite not suitable for the removal of $\mathrm{Cr}(\mathrm{VI})$ from its industrial effluents. This adsorbent can be applied after appropriate dilution of the industrial effluent for the removal of $\mathrm{Cr}(\mathrm{VI})$ or after removing the co-metals present in the effluent.

\section{References}

1. Mata YN, Blazquez ML, Ballester A, Gonzelez F, Munoz JA (2009) Biosorption of cadmium, lead and copper with calcium alginate xerogels and immobilized Fucus vesiculosus. J of Hazard Mater 163: 555-562.

2. Verma A, Chakraborty S, Basu JK (2006) Adsorption study of hexavalent chromium using tamarind hull-based adsorbents. Sep Purif Technol 50: 336341.

3. Ahluwalia SS, Goyal D (2005) Removal of heavy metals by waste tea leaves from aqueous solution. Eng Life Sci 5: 158-162.

4. Malkoc E, Nuhoglu Y (2006) Fixed bed studies for the sorption of chromium(VI) onto tea factory waste. Chem Eng Sci 61: 4363-4372.

5. Sarin V, Pant KK (2006) Removal of chromium from industrial waste by using eucalyptus bark. Bioresour Technol 97: 15-20.

6. Karthikeyan T, Rajgopal S, Miranda LR (2005) Chromium(VI) adsorption from aqueous solution by Hevea Brasilinesis sawdust activated carbon. J Hazard Mater 124: 192-199.

7. Acar FN, Malkoc $E$ (2004) The removal of chromium(VI) from aqueous solutions by Fagus orientalis L. Bioresour Technol 94: 13-15.

8. Chen GQ, Zeng GM, Tu X, Niu CG, Huang GH, et al. (2006) Application of a by-product of Lentinus edodes to the bioremediation of chromate contaminated water. J Hazard Mater 135: 249-255.

9. Ahluwalia SS, Goyal D (2006) Microbial and plant derived biomass for removal of heavy metals from wastewater. Bioresour Technol 98: 2243-2257.

10. Kumar KV, Ramamurthi V, Sivanesan S (2006) Biosorption of malachite green, a cationic dye onto Pithophora sp., a fresh water algae. Dyes Pigments 69: 102-107.

11. Fonseca MG, Oliveira MM, Arakaki LNH (2006) Removal of cadmium, zinc, manganese and chromium cations from aqueous solution by a clay mineral. $J$ Hazard Mat 137: 288-292.

12. Sarioglu M, Atay UA, Cebeci $Y$ (2005) Removal of copper from aqueous solutions by phosphate rock. Desalination 181: 303-311.

13. Uddin MB, Mukul SA, Khan MA SA, Chowdhury MSH Uddin MS, Fujikawa S (2006) Indigenous management practices of Hogla (Typha elephantina Roxb.) in local plantations of floodplain areas of Bangladesh. J Subtrop Agric Res Dev 4: $114-119$
14. Andrew DE, Lenore SC, Eugene WR, Arnold EG (2005) Standard methods for the examination of water and wastewater.

15. Kumar YP, King P, Prasad VSRK (2007) Adsorption of zinc from aqueous solution using marine green algae - Ulva fasciata sp. Chem Eng J 129: 161166.

16. Malkoc E, Nuhoglu Y (2007) Determination of kinetic and equilibrium parameter of the batch adsorption of $\mathrm{Cr}(\mathrm{VI})$ onto waste acorn of Quercus ithaburensis. Chem Engg Process 46: 1020-1029.

17. Hasan ZR, Cloirec P (2002) Uranium adsorption by filamentous fungus Maier meihei. Wat Res 26: 1139-1145.

18. Priya AJ, Gajulapalli SR, Abburi K, Boddu VM (2008) Biosorption of chromium, copper, and nickel ions by tamarindus indica fruit nut testa. Bioremed $\mathrm{J} 12$ : $145-155$.

19. Park D, Yun YS, Park JM (2005) Studies on hexavalent chromium biosorption by chemically treated biomass of Ecklonia sp. Chemosphere 60: 1356-1364.

20. Rao M, Parvate AV, Bhole AG (2002) Process development for removal of copper and lead from aqueous solution by low cost material. J Environ Poll 22: $17-25$

21. Bishnoi NR (2004) Biosorption of $\mathrm{Cu}$ (II) from aqueous solution using algal biomass. J Sci Ind Res 63: 813-816.

22. Juang RS, Wu FC, Tseng RL (1997) The ability of activated clay for the adsorption of dyes from aqueous solutions. Environ. Technol 18: 525-531.

23. D“onmez G, Aksu Z (2002) Removal of chromium(VI) from saline wastewaters by Dunaliella species. Process Biochem 38: 751-762.

24. Bai SR (2003) Abraham ET biosorption of $\mathrm{Cr}$ (VI) from aqueous solution by Rhizopus nigricans. Bioresour Technol 79: 73-81.

25. Dursun G, Cicek H, Dursun AY (2005) Adsorption of phenol from aqueous solution by using carbonised beet pulp. J Hazard Mater B125: 175-182.

26. Akkaya G, Ozer A (2005) Adsorption of acid red 274 (AR 274) on Dicranella varia: Determination of equilibrium and kinetic model parameters. Process Biochem 40: 3559-3568.

27. Pearce Cl, Lloyd JR, Guthrie JT (2003) The removal of color from textile wastewater using whole bacterial cells: A review. Dyes Pigments 58: 179-196.

28. Malkoc $E$ (2006) Ni(II) removal from aqueous solutions using cone biomass of Thuja orientalis. J Hazard Mater 137: 899-908.

29. Ho YS, McKay G (1999) Pseudo second order model for sorption processes Process Biochem 34: 451-465.

30. Mallick S, Dash SS, Parida KM (2006) Adsorption of hexavalent chromium on manganese nodule leached residue obtained from NH3-SO2 leaching. J Colloid and Interface Sci 297: 419-425.

31. Hu J, Chen G, Lo IMC (2005) Removal and recovery of Cr(VI) from wastewater by maghemite nanoparticles. Water Res 39: 4528- 4536.

32. D"onmez GC, Aksu Z, Ozturk A, Kutsal T (1999) A comparative study on heavy metal biosorption characteristics of some algae. Process Biochem 34: 885892.

33. Sharma DC, Foster CF (1994) A preliminary examination into the adsorption of hexavalent chromium using low-cost adsorbents. Bioresour Technol 47: 257-264.

34. Babel S, Kurniawan TA. Sharma DC, Foster CF (1994) A Preliminary examination into the adsorption of hexavalent chromium using low-cost adsorbents. Bioresour Technol 47: 257-264.

35. Babel S, Kurniawan TA (2000) Cr(VI) removal from synthetic wastewater using coconut shell charcoal and commercial activated carbon modified with oxidizing agents and/or chitosan. Chemosphere 54: 951- 967.

36. Cimino G, Passerini A, Toscano G (2000) Removal of toxic cations and $\mathrm{Cr}(\mathrm{VI})$ from aqueous solution by hazelnut shell. Water Res 34: 2955-2962.

37. Romero-Gonz'alez J, Peralta-Videa JR, Rodrı̌ıguez E, Ramirez SL, GardeaTorresdey JL (2005) Determination of thermodynamic parameters of $\mathrm{Cr}(\mathrm{VI})$ adsorption from aqueous solution onto Agave lechuguilla biomass. J Chem Thermodyn 37: 343-347.

38. Muhammad R, Nadeem R, Hanif MA, Ansari TM, Rehman KU (2009) Pb (II) biosorption from hazardous aqueous streams using Gossypium hirsutum (Cotton) waste biomass. J Hazar Mat 161: 88-94. 